\title{
Status Isonômico das Leis Complementares e Leis Ordinárias no Direito Tributário Brasileiro
}

\author{
Dieqo Ferreira
}

\section{INTRODUÇÃO}

A presente monografia tem como escopo analisar o status hierárquico entre a Lei Complementar e a Lei Ordinária, ou seja, especificamente, averiguar se há ou não hierarquia entre estas normas.

O tema tem gerado grandes discussões entre os doutrinadores tanto nacionais como estrangeiros, face a repercussão junídica Que a abordagem diferenciada da temática pode acarretar no sistema tributário pátrio.

Melhor esclarecendo tem-se a colaboração de Alexandre Morais:

Discussão eternizada na doutrina, a eventual existência ou não de hierarquia entre lei complementar e lei ordinária obteve de ambos os lados grandes juristas e brilhantes argumentaçōes'

A Questão reverte-se de maior complexidade e relevância na medida em Que a controvérsia doutrinária acima referida é também vislumbrada nos julgados de nossos Tribunais Superiores.

Outrossim, deve-se frisar Que para o Direito Tributário o estudo concentrado na Questão da hierarquia entre Lei Complementar e Lei Ordinária, certamente, tem maior importância do Que para outros ramos do direito, pois o Sistema Tributário Nacional prevê inúmeras vezes a utilizaçãa da lei complementar.

A doutrina e a jurisprudência, como se perceberá, encontram-se bastante divididas.

\footnotetext{
'MORAIS, Alexandre. Direito Constitucional. Nova Ediçäo. São Paulo, 2001, p. 533.
} 
Aqueles que defendem a tese da inexistência de hierarquia entre Lei Complementar e Lei Ordinária sustentam que a Constituição Federal não estabeleceu hierarquia entre estas normas, mas tão somente determinou Quais as matérias devem ser tratadas por meio de lei complementar. Desta forma, se lei ordinária versasse sobre matéria reservada à lei complementar seria inconstitucional, uma vez que a Carta Magna exigiria para o caso Lei Complementar. Todavia, se ocorresse o inverso, ou seja, Lei Complementar versasse sobre matéria de Lei Ordinária, teria aquela valor e eficácia de Lei Ordinária.

Por outro lado, os doutrinadores que sustentam a existência de hierarquia entre Lei Complementar e Lei Ordinária, referem Que o texto constitucional ao prever o processo legislativo, estabeleceu a hierarquia entre as normas, estando a Lei Complementar em grau superior à Lei Ordinária. Outro argumento é de que a superioridade da Lei Complementar sobre a Lei Ordinária se revela Quando a própria Constituiçāo Federal requer para sua aprovação Quorum Quallficado. Desta forma, sempre Que houvesse edição de Lei Complementar, versando sobre determinada matéria, mesmo que não fosse matéria de Lei Complementar, a Lei Ordinária não poderia mais revogá-la.

Destarte, para uma melhor abordagem do tema proposto, dividiu-se a monografia em dois capítulos, onde, no primeiro, se analisará a Questão da competência legislativa tributária, procurando estabelecer sua definição, a necessidade de distribuição da competência em face do princípio Federativo, as espécies de competência e o significado das normas gerais em Direito Tributário

No segundo, primeiramente, tecem-se alguns comentários acerca da definição e do processo legislativo tanto da Lei Complementar Quanto da Lei Ordinária. Após, analisam-se as finalidades da Lei Complementar. E, por derradeiro, adentra-se no tema em específico.

Portanto, a presente monografia pretende tecer comentários a respeito do tema da hierarQuia entre a Lei Complementar e Lei Ordinária, buscando demonstrar se existe hierareuia ou isonomia entre estes instrumentos normativos. 


\section{COMPETÊNCIA LEGISLATIVA TRIBUTÁRIA}

\subsection{Definição de competência}

Primeiramente, deve-se esclarecer Que o termo "competência tributária" não se confunde com o termo "poder tributário", ainda Que haja conexão entre ambos.

Diz-se isso, pois competência tributária segundo a ótica de Maristela Miglioli Sabbag é "a manifestação da autonomia da pessoa política que a detém" ${ }^{\prime 2}$ com suporte no princípio da Federação, consubstanciado no art. $1^{\circ}$ da Constituição Federal de 1988, em Que cada uma das pessoas políticas internas possui autonomia. Em contrapartida, o poder tributário. conforme a mesma doutrinadora, se operaria "lão-somente no âmbito dos Estados unitários, nos quais existe uma única pessoa política central, imbuída do poder absoluto de tributar, sem Quaisquer restrições".

Não obstante o acima expedido, a doutrina mais abalizada rechaça essa diferenciação acadêmica baseada no autoritarismo do Estado, haja vista entenderem Que "competência tributária" e "poder tributário" estão presentes em todo o Estado Constitucional. ${ }^{4}$

Noutros termos, pode-se dizer que o poder tributário é o jus imperium do Estado em manifestação de sua soberania, sendo originalmente liimitado. Com a organização jurídica do Estado o poder tributário passa a ter limitações vinculadas às normas que definem a sua atuação, surgindo, então, a competência tributária. ${ }^{5}$

Nessa mesma linha de entendimento, encontra-se o magistério de José Souto Maior Borges, o qual assevera Que a competência tributária consiste "numa autorização e limitação constitucional para o exercício do poder tributário". 6

Em vista disso, a competência tributária apenas pode ser exercida mediante lei, em observância ao princípio da legalidade tributária.

Destarte, a competência tributária segundo Roque Antonio Carraza

(...) é a possibilidade de criar, 'in abstracto;, tributos, descrevendo, legislativamente, suas hipóteses de incidência, seus sujeitos ativos, seus sujeitos passivos, suas bases de cálculo e suas alíquotas. ${ }^{7}$

${ }^{2}$ SABBAG, Maristela Migliohi. Competência Tributária. Revista os Tribunais, São Paulo, jun. 1996, v. 728, p. 682.

${ }^{3}$ Idem, ibidem,

${ }^{4}$ MACHADO, Hugo de Brito. Curso de direito tributário. 12. ed. Săo Paulo: Malheiros, 1997, p. 25

s MACHADO, Hugo de Brito. Curso de Direito Tributário. 18 ed. Săo Paulo: Matheiros, 2000, p. 212.

${ }^{6}$ BORGES, josé Souto Maior. Isençōes Tributárias. 2. ed. São Pauło: Sugestões Literárias, $1980, \mathrm{p} .18$.

${ }^{7}$ CARRAZA, Roque Antonio. Curso de Direito Constitucional Tributário. I7 ed, São Pauto: Malheiros, 2002. p. 345 . 
Portanto, a expressão "competência tributária" pode ser definida como sendo o poder, atribuido pela Constituição Federal, observadas as normas gerais de Direito Tributário, de instituir e fiscalizar o cumprimento das obrigações tributárias, compreendendo a competência legislativa e administrativa.

\subsection{Distribuição de competência}

Não se pode olvidar que o princípio Federativo adotado pelo Estado Brasileiro, Que denota uma carga de autonomia aos entes políticos, exige uma distribuição, repartição ou mesmo discriminação de competências tributárias.

A repartição da competência, consoante o entendimento de Aliomar Baleeiro, é essencial à estrutura federal de Estado, de modo que cada ordem jurídica parcial, que somente vale dentro do âmbito territorial de cada ente descentralizado, possa nascer de Poder Legislativo próprio daquele ente estatal descentralizado. ${ }^{8}$

Em vista disso, a distribuição/repartição da competência vem expresso no art. $145^{\circ}$ da Constituição Federal de 1988, Quando estatui que a União, os Estados, o Distrito Federal e os Municípios poderão instituir tributos.

Outrossim, a Constituição Federal em seus artigos. 153. 155 e 156, sob as epígrafes "Dos impostos da União", "Dos impostos dos Estados e do Distrito Federal" e "Dos impostos dos Municípios", estabeleceu a competência desses entes políticos. Há de se atentar ainda para a competência residual da União, em observância ao art. 154 da Carta Constitucional,

Diante do exposto, infere-se Que a repartição de competências tributária, como já se disse, decorre "da própria estrutura do Estado Federado e, para Que tenha condições de plena eficácia, deve ser rígida e exaustiva, objetivando prevenir os conflitos e invasões de uma pessoa política por outra". 10

Por fim, urge deixar claro Que a distribuição de competência tributária definida pela CF é taxativa, não admitindo Quaisquer invasões entre os entes fiscais, pois a Constituição oferece titularidade ou exclusividade dos tributos à União, Estados, ao Distrito Federal e Municípios. Assim, Qualquer tentativa no sentido de instituir tributo alheio a competência do ente restará infrutífera, pois este será incompetente. Da mesma forma será considerada nula a lei Que usurpa competência tributária alheia, garantindo o direto de restituição à Quem Quer Que tenha pago indevidamente o tributo.

\$ BALEEIRO, Aliomar. Direito Tributário Brasileiro. Atualização: Misabel Abreu Machado Derzi. Rio de Janeiro: Forense, 2004, p. 40.

- Importante salientar Que o artigo 145 da Constituição Federal de 1988 não é o único dispositivo Que encerra normas de distribuição e repartição de competência. Veja-se também artigos 148 e 149 da Carta Magna, entre outros.

10 SABBAG, Maristela Miglioli. Op. cit., p. 684. 


\subsection{Espécies de competência}

Primeiramente, é oportuno frisar Que os doutrinadores não são harmônicos Quanto ao número de espécies de competência tributária. "

De Qualeuer sorte, no âmbito da repartição de competências, corolário do princípio Federativo, mencionam-se as seguintes, Quais sejam:

a) competência cumulativa ou comum - encontra-se disciplinada no art. 145, II e III, da Constituição Federal de 1988, sendo aQuela atribuída a uma ou mais entidades políticas, como, por exemplo, a Que possibilita a cobrança das 'taxas' e 'contribuição de me!horia' pela União, Estados Distrito Federal e Municípios, evidentemente dentro das respectivas competências de atuação.

b) competência privativa ou exclusiva - é a atribuída específica e exclusivamente a um ente politico, ou seja, ocorre euando apenas uma pessoa política pode tributar sobre determinada base econômica, excluindo-se a competência dos demais entes, como no caso do Imposto sobre Produto Industrializado - IPI.

c) competência residual - é o poder de instituir outros tributos não previstos na Constituição Federal, em seus artigos I53,154 e 155. No Brasil, cabe ressaiłtar, somente a União detém a competência residual, nos termos do art. 154.

d) competência legislativa plena - é o poder de legislar sobre todos os aspectos do tributo, tais como fato gerador, base de cálculo, alípuota, contribuintes, entre outros, consoante disposto no art. $6^{\circ}$ do Código Tributário Nacional - CTN, observando-se as normas gerais de direito tributário.

e) competência legislativa supletiva ou suplementar - é a atribuída aos Estados, ao Distrito Federal e aos Municípios para, nas suas respectivas esferas, editarem normas complementares, nos termos do art. $24, \S 2^{\circ}$, da Constituição Federal.

f) competência concorrente - é a competência atribuída pela Constituição Federal aos três níveis de governo para legislar sobre direito tributário, consoante a dicção do art. 24 .

Portanto, como se pode perceber, é a Constituição Federal @uem atribui competência em matéria tributária, Que, sintetizando o pacto federativo, traça os contornos gerais do Estado nas suas três esferas de poder. Como expressão pura desse pacto ela distribui as competências tributárias entre a União, os Estados, o Distrito Federal e os Municípios, formando, juntamente com os princípios e regras de direito tributário, o Sistema Tributário Nacional.

"Cf. ICHIHARA, Yoshiaki. Direito Tributário. 6. ed. São Paulo: Atlas, 1994, p. 30 e ss. e DECOMAIN. Pedro Roberto. Anotações ao Código Tributário Nacional. São Paulo: Saraiva, 2000, p. 44 e ss. 


\subsection{Significado das normas qerais Tributárias como pressuposto ao estudo da lei complementar à luz da Constituição de 1988}

Quanto à definição do Que sejam as chamadas "normas gerais", o certo é que nenhuma doutrina conseguiu estabelecer uma definição rigorosa.

A respeito desse problema da identificação da extensão do conceito de normas gerais, Fernanda Dias Menezes de Almeida, versando sobre a extensão das competências outorgadas pelo Texto Constitucional, leciona:

O grande problema Que se coloca, a propósito, é o da formulação de um conceito de normas gerais Que permita reconhecê-las, na prática, com razoável segurança, já Que a separação entre normas gerais e normas Que não tenham esse caráter é fundamental. ${ }^{12}$

Na busca de uma melhor compreensão do significado das normas gerais, deve-se frisar a lição de Carvalho Pinto, Que estabeleceu uma delimitação negativa, ou seja, estabelecendo o Que não pode ser considerada como norma geral. Diz o autor:

a) Não são normas gerais as Que objetivem especialmente uma ou algumas dentre várias pessoas congêneres de direito público, participantes de determinadas relações jurídicas; b) não são normas gerais as Que visem. particularizadamente, a determinadas situações ou institutos, com exclusão de outros, da mesma condição ou espécie; c) não são normas gerais as que se afastem dos aspectos fundamentais ou básicos, descendo a pormenores ou detalhes. ${ }^{13}$

Sacha Calmon Navarro Coêlho definju as normas gerais, nos seguintes termos:

As normas gerais de Direito Tributário, veiculadas pelas leis complementares, são eficazes em todo o território nacional, acompanhando o âmbito de validade espacial destas, e se endereçam aos legisladores das três ordens de governo da Federação, em verdade, seus destinatários. A norma geral articula o sistema tributário da Constituição às legislações fiscais das pessoas políticas (ordens jurídicas parciais). São normas sobre como fazer normas em sede de tributação. ${ }^{14}$

\footnotetext{
i2 ALMEIDA, Fernanda Dias Menezes de. Competências na Constituiçăo de 1988. 2. ed. São Paulo: Atlas, 2000, p. 146.

${ }^{13}$ PINTO, Carvalho apud Heleno Taveira Tôrres. Funçốes das Leis Complementares no Sistema Tributário Nacional: hierarquia de normas. Revista de Direito Tributário, São Paulo, n. 84, p. 55-56.

${ }_{14}$ COÊLHO, Sacha Calmon Navarro. Curso de Direito Tributário Brasileiro. 2. ed. Rjo de laneiro: Forense, 1999 , p. 109.
} 
A definição deste último autor, sem dúvida, foi influenciada pelo pensamento Ponteano, pois no Que diz respeito as normas gerais do Direito Tributário nos ensina Pontes de Miranda:

Não se trata de lei de tributação, mas sim de lei sobre leis de tributação. ${ }^{15}$

Assim, partindo-se de uma leitura do art. 146, da Constituição Federal de 1988 , normas gerais somente serão aQuelas que venham a ser criadas, Quando o Legislativo da União, revestindo-se das magnas funçôes de legislador nacional, as introduza no ordenamento рага:

"a) definição de tributos e de suas espécies, bem como, em relação aos impostos discriminados nesta Constituição, a dos respectivos fatos geradores, bases de cálculo e contribuintes; b) obrigação, lançamento, crédito, prescrição e decadência tributários; c) adeQuado tratamento tributário ao ato cooperativo praticado pelas sociedades cooperativas; e, d) definição de tratamento diferenciado e favorecido para as microempresas e para as empresas de pequeno porte, inclusive regimes especiais ou simplificados no caso do imposto previsto no art. 155, II, das contribuiçōes previstas no art. 195, I e $\S \S 12$ e 13, da contribuição a Que se refere o art. 239, no Imposto sobre Serviço de Qualeuer Natureza - ISS no Imposto Sobre Circulação de Mercadorias e Prestação de Serviço - ICMS.

As normas gerais de Direito Tributário são normas que objetivam o equilíbrio do subsistema tributário nacional, as Quais, em hipótese alguma, restringirão as competências previamente outorgadas pela Constituição Federal de 1988. Tal fato ocorre, pois somente Quem atribui a competência poderá, em outro momento, limitar seu exercício. Assim, a Constituição Federal é que restringe as competências Que ela própria outorgou - e nunca a norma geral nacional.

Neste diapasão cabe salientar as ponderações de Renato Romeu Renck no Que concerne a superioridade hierárquica no tocante as normas de estrutura:

Quando se estiver diante de normas Que, para serem aplicadas ao caso concreto, dependem da aplicação de outra norma, pode-se falar em hierarQuia. (...) Assim, pode-se ver Que há hierarquia no âmbito das competências concorrentes, previstas no art. $24 \mathrm{da}$ Carta, Quando a Federação legisla em termos de norma geral e a suplementação é feila pelos Estados e Municípios. Há, pois, duas competências distintas: uma para traçar normas gerais, conferida à Federação, e outra para suplementa-las, conferida aos EstadosMembros. Haverá hierarquia entre normas, lão-somente se a norma federal

${ }^{15}$ MIRANDA, Pontes de. Comentários à Constituiçẫo de 1967. São Paulo: RT, 1967, t.il, p. 369. 
for de estrutura de outras normas inferiores. No caso das normas gerais incluindo as de natureza concorrente - , a hierarquia se estabelece em face dos contornos - tanto materiais como formais, que são criados e Que circunscrevem os limites da competência dos Estados. ${ }^{16}$

\section{LEI COMPLEMENTAR E LEI ORDINÁRIA}

\subsection{Consideraçóes gerais acerca da lei complementar e da lei ordinária como FUNdAMENTO dE ISONOMIA ENTRE ESTES INSTRUMENTOS NORMATIVOS}

Inicialmente, antes de se adentrar na análise específica acerca da existência ou não de hierarquia entre a lei complementar e a lei ordinária, faz-se necessário tecer algumas consideraçỏes gerais sobre o processo de criação destas normas.

A lei complementar brasileira tem por origem o direito constitucional francês, onde existe a chamada loi organique que tem como conteúdo material a estruturação e organização dos Poderes Públicos.

A lei complementar pode ser definida como sendo aquela Que, dispondo sobre matéria, expressa ou implicitamente, prevista na redação constitucional, está submetida ao Quorum Qualificado previsto no art. 69 da Constituição Federal de 1988.

Desta forma, a votação visando a aprovação de lei complementar, será realizada mediante apuraçăo da maioria absoluta dos votos dos integrantes de cada Casa Legislativa.

A sanção, a promulgação e a publicação da lei complementar caberá ao Presidente da República, tendo em vista a incidência do art. 66 , caput e $\S 7^{\circ}$, da $\mathrm{CF} / 88$.

Destarte, as leis complementares são entes legislativos reconheciveis formal e materialmente.

Sob o ponto de vista formal, a lei complementar da Constituição Federal é aquela votada por maioria absoluta (Quorum de votaçāo de metade mais um dos membros do Congresso Nacional), por força do art. 69 , da $\mathrm{CF} / 88$.

Sob o ponto de vista material, a Lei Complementar da Constituição Federal é aquela Que tem por objetivo a complementação da Constituiçã̃o, Quer aisuntando-the normatividade, Quer operacionalizando-the os comandos.

:6 RENCK, Romeu Renato. Imposto de Renda da Pessoa lurídica. Do Advogado, 2001, p: 67/68. 
A lei ordinária, por sua vez, pode ser elaborada pelos Poderes Legisiativos da União, Estados, Distrito Federal e Municípios, de conformidade com a competência material outorgada pela Constituição Federal, exigindo para sua aprovação tão somente maioria simples.

Em vista disso, pode-se perceber que o órgão de emissão da lei complementar é o mesmo Que emite a lei ordinária, assim como o âmbito de validade espacial. Nessa aspecto as leis complementares e as leis ordinárias são idênticas.

Assim, pode-se esclarecer Que a presença do processo legislativo especial e Qualificado na lei complementar é que confere a esta uma nítida distinção em relação à lei ordinária.

Portanto, o processo de inserção de lei complementar no ordenamento jurídico brasileiro distingue-se daquele referente à legislação ordinária somente no que concerne ao Quorum exigido para a aprovação do projeto correlato, nas duas casas legislativas, Que compóem - Congresso Nacional. Para a anuência de norma ordinária impõe-se a maioria simples, a Qual se perfaz com número de votos correspondente a QualQuer fração superior à metade dos presentes à sessão. A aceitação de proposta de lei complementar, contudo, subordina-se à aquiescência da maioria absoluta dos membros, a qual se obtém com a manifestação positiva de mais da metade dos componentes de cada plenário.

De outra banda, cabe destacar a natureza política no tocante à exigência de lei complementar adotada pela Constituição Federal de 1988, destacada pelo Ministro Nelson lobim:

Em relação à exigência de lei complementar Que a Constituição de 1988 adota, Quer-me parecer que as decisões para a escolha de ser lei ordinária ou lei complementar são de natureza política, e o foram na Constituição de 1988. Na verdade, a Constituição continuou exigindo lei complementar porque a situação anterior a 88 exigia, ou passou a exigir lei complementar por situações exclusivamente políticas...Toda a decisão, portanto, em determinar lei complementar ou não, é uma decisão política no sentido de se exigir um tipo de maioria qualificada para decidir determinada matéria. Não há nenhuma razão essencialista, na Constituição de 88 , para se exigir a lei complementar. (.......não há Que se fazer interpretaçôes ou exegeses de Qualquer natureza, se tentar ler o Que na Constituição nāo está. Se está lei, é lei, não será lei complementar, salvo se ela for remissiva - aQuii, há uma opção específica do legislador. Esta era a técnica legislativa, em 1988, para se compor determinados tipos de conflitos políticos não-resolvidos no seio da Assembléia Nacional Constituinte: recorria-se a alguns instrumentos e um deles era esta espécie de acordo dilatório, de jogar pra frente algo que não se poderia decidir naquele momento. E para se jogar pra frente, jogar-se para legislação, optava-se pela legislação complementar ou pela lei ordinária, 
dependendo da natureza da matéria e do grau de controvérsia que houvesse no seio da Assembléia. A outra técnica Que se utilizou, e que a Constituição utiliza, foi dos advérbios de modo, no processo legislativo, em que se minimiza basicamente o texto. ${ }^{17}$

\subsection{Finalidades da lei complementar}

Alguns eminentes juristas pátrios entendiam, em face da redação do art. $\left[8, \S 1^{\circ}\right.$, da Emenda Constitucional n. $1 / 69^{18}$ Que era dupla a função da lei complementar. A maioria da doutrina, entretanto, encampou a tríplice função, ou seja, a de estabelecer normas gerais, prevenir conflitos de competência e regular as limitações constitucionais ao poder de tributar.

A tríplice função da lei complementar está descrita no art. 146, da Constituição Federal de 1988, segundo o Qual dita, in verbis.

Art. 146 - Cabe à lei complementar:

I - dispor sobre conflitos de competência, em matéria tributária, entre a União, os Estados, o Distrito Federal e os Municípios;

II - regular as limitações constitucionais ao poder de tributar;

III - estabelecer normas gerais em matéria de legislação tributária, especialmente sobre:

O primeiro aspecto referido pela Constituição é o de que a lei complementar dispõe sobre conflitos de competência, em matéria tributária, entre a União, Estados, Distrito Federal e Municípios.

O segundo inciso faz menção às limitações ao poder de tributar expostas na Constituição, reproduzindo o discurso anterior.

Se a limitação é ao poder de tributar, tal limitação refere-se à faculdade que o Poder tributante tem de tributar. Se a limitação fosse do poder de tributar, tal limitação referir-seia ao próprio Poder tributante. A configuração gramatical, todavia, não altera o produto final da limitação, Qưe impõe restrições, de rigor, à faculdade e ao próprio poder, por decorrência.

Por fim, a função de estabelecer normas gerais de legislação tributária. Com efeito, há normas gerais Que são estruturalmente normas gerais e outras Que têm o perfil de normas gerais porque são veiculadas por lei complementar; como há normas constitucionais que só ganham tal delineamento porque surgem no texto constitucional, mas cuja estrutura é de legislação complementar ou ordinária.

\footnotetext{
17 Excerto do voto do Ministro Nelson Jobim no RE n. 225.602-8, novembro/I 988.

${ }^{18}$ Emenda Constitucional n. 1/1969, Constituiçâao Federal de 1967: Art. 18, Caput: Além dos impostos previstos nesta Constituição, compete à União, aos Estados, ao Distrito Federal e aos Municípios instituir. Parágrafo primeiro: Lei complementar estabelecerá normas gerais de direito tributário, disporá sôbre os confiltos de competência nesta matéria entre a União, os Estados, o Distrito Federal e os Municípios, e regulará as timitações constitucionais do poder de tributar.
} 


\section{3 a Questão da Hierarouia Entre lei Complementar e Lei Ordinánia}

O sistema jurídico é constituído por um conjunto de normas em que as partes se harmonizam com o todo e o todo com as partes, formando um conjunto único e harmônico.

Segundo Francisco Ribeiro dos Santos "as normas do ordenamento jurídico formam uma estrutura totalizadora, sendo o todo considerado como unidade, por sintetizarem-se nele os conceitos de unidade e pluralidade". ${ }^{19}$

Entretanto, as normas Que compõem o ordenamento jurídico não possuem entre si a mesma hierarquia, mas são compostas de degraus hierareuizados.

Nesse sentido, aliás, é o magistério de fuarez Freitas, o qual conceitua o sistema jurídico:

Como sendo uma rede axiológica e hierarquizada de princípios gerais e tópicos, de normas e de valores jurídicos cuja função é a de, evitando ou superando antinomias, dar cumprimento aos princípios e objetivos fundamentais do Estado Democrático de Direito, assim como se encontram consubstanciados, expressa ou implicitamente na Constituição. ${ }^{20}$

Para explicar este fenômeno, Hans Kelsen idealizou sua pirâmide jurídica demonstrando que as normas são hierarquizadas e que o fundamento de validade está em Que a inferior extrai sua validade na superior. ${ }^{21}$

Em vista disso, a leitura de nosso sistema jurídico positivo, mais especificadamente do art. 59 da Constituição Federal de 1988, poderia levar a conclusão da existência de hierarquia entre as normas jurídicas, segundo a pirâmide kelsiana, já que estabelece, in verbis:

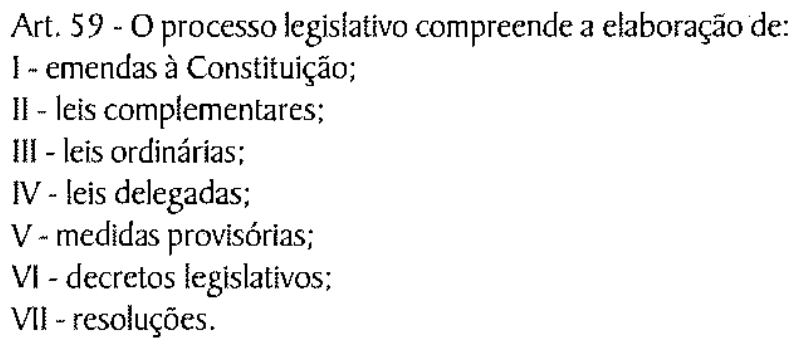

\footnotetext{
"SANTOS, Francisco Ribeiro dos, apudICHIHARA, Yoshiaki. Op. cit., p. 33.

${ }^{20}$ FREITAS, Juarez. A Interpretação Sistemática do Direito. 2. ed. São Paulo: Malheiros, 1998, p. 46.

21 KELSEN, Hans. Teoria Pura do Direito, p. $26 \%$.
} 
Deve-se referir que a problemática em torno da hierareuia entre a lei complementar e a lei ordinária, surge, sobretudo, após a alteração realizada no artigo 46 da Constituição de 1967 (correspondente ao artigo 49 da redação original) pela Emenda n. 1/69, onde grande parte da doutrina, sobretudo a partir da obra de Miguel Reale, passou a considerar as leis complementares como sendo uma espécie legislativa hierarquicamente superior a lei ordinária, sendo caracterizada como um tertius genus normativo. ${ }^{22}$

Nessa linha, pode-se observar o magistério de Manoel Gonçalves Ferreira Filho:

Analisando esse texto. Miguel Reale demonstrou serem estas leis um 'tertium genus' de leis, Que não ostentam a rigidez dos preceitos constitucionais, nem tampouco devem comportar a revogação (perda de vigência), por força de Qualquer lei ordinária superveniente. ${ }^{23}$

Ainda, nesse sentido, lembra Maria do Rosário Esteves, Que:

juristas de escol como Pontes de Miranda, Miguel Reale, Manoel Gonçalves Ferreira Filho e outros sustentam ser a lei complementar um 'tertium genus' interposto, na hierareuia dos atos normativos, entre a lei ordinária e a Constituição. ${ }^{24}$

Conforme esclarece José Souto Maior Borges, fundamentava-se a referida superioridade da lei complementar nos seguintes termos:

I- O art. 46 da Constituição de 1967, com redação que the deu a Emenda n. 1/69 colocou logo abaixo das emendas à Constituição (item I), as leis complementares (item II), revelando a sua posição hierárquica, entre as regras jurídicas componentes do ordenamento jurídico nacional, superior à da lei ordinária;

II - A lei complementar é formalmente superior à lei ordinária porque esta não pode alterá-la ou revogá-la sendo nula a parte da lei ordinária Que contravenha dispositivo de lei complementar, mas inversamente a lei complementar revoga e altera a legislação ordinária;

III - O Quorum especial e Qualificado, estabelecido para a sua aprovação. conferiria à lei complementar uma 'superioridade formal' ou 'eficacial' com relação à lei ordinária. ${ }^{25}$

22 REALE, Miguel. Parlamento Brasileiro. São Paulo: Saraiva, 1962, p. 110-111.

${ }^{23}$ FERREIRA FILHO, Manoel Gonçalves. Comentários à Constituiçăo Brasileira. São Paulo: Saraiva, 200 1, p. 260.

${ }^{24}$ ESTEVES, Maria do Rosário. Normas Gerais de Direito Tributário. São Paulo: Max Limonad, 1997, p. 80.

${ }^{25}$ BORGES, José Souto Maior. Lei Complementar Tributária. São Paulo: Revista dos Tribunais, 1975, p. 19-20. 
Outrossim, Yoshiaki Ichihara defende a hierareuia entre a lei complementar e a lei ordinária. Sustenta o doutrinador:

Dentro da hierareuia, sem dúvida alguma, a lei complementar coloca-se em superioridade se comparada à lei ordinária, pelo seu aspecto formal de exigência do Quorum Qualificado e Quando esta lei aparece como sobrenorma ou estabelece normas gerais necessárias à edição da lei ordinária. ${ }^{26}$

A respeito da superioridade da lei complementar sobre a lei ordinária, deve-se referir o posicionamento de Geraldo Ataliba, segundo o eual:

Abaixo das leis constitucionais, localizou as complementares, seguidas imediatamente das ordinárias. A hierarquia ideal corresponde a esta gradação. A principal conseoüência jurídica desta circunstância reside na superioridade da lei complementar sobre a ordinária. E esta graduação tem, em muitos casos, conseQüências também de caráter formal.

Consiste a superioridade formal da lei complementar - como em geral das normas jurídicas eminentes, em relação às Que the são inferiores - na impossibilidade jurídica de a lei ordinária alterá-la ou revogá-la. Nula é, pois, a parte desta Que contravenha disposição daquela.

Inversamente, a lei complementar revoga e altera a ordinária, impondo em outros casos absoluto afeiçoamento desta àouela, pelo menos puanto ao espírito. $^{27}$

Para Ives Gandra Martins, também, há hierarquia, pois segundo o autor, a lei complementar":

é norma de integração entre os princípios gerais da Constituição e os comandos de aplicação da legislação ordinária, razão pela Qual, na hierarquia das leis, posta-se acima destes e abaixo daqueles. Nada obstante alguns autores entendam que tenha campo próprio de atuação, no uue têm razão, tal esfera própria de atuação não pode, à evidência, nivelar-se àquela outra pertinente à legislação ordinária. A lei complementar é superior à lei ordinária, servindo de teto naquilo que é de sua particular área mandamental. ${ }^{28}$

${ }^{26}$ ICHIHARA, Yoshiaki. Op. cit., p. 93.

I ATALIBA, Geraldo. Lei Complementar na Constituição. São Paulo: Revista dos Tribunais, 1969, p. 29. Deve-se esclatecer que o professor Geraldo Ataliba, diante das críticas apresentadas pelo Prof. losé Souto Maior Borges, modificou seu posicionamento, passando, então, a defender a tese da inexistência de hierarquia entre a lei ordinária e a lei complementar.

${ }^{28}$ MARTINS, Ives Gandra. Sistema Tributário na Constituição de 1988. 5. ed. São Paulo: Saraiva, 1998, p. 69. 
Ademais, há que se salientar Que segundo Vittorio Cassone, trata-se de Questão tanto de competência quanto de hierarquia, na medida em Que defende que:

a lei ordinária, ao tratar do tipo tributário, deve respeitar a lei complementar - desencadeando, nessa oportunidade, o fenômeno da hierareuia das leis, ou seja, se ela não respeitar o campo de incidência fixado pela lei complementar, incorre em desobediência hierárquica Que provoca a declaração de inconstitucionalidade (invasão da competência constitucional conferida à lei complementar).

Trata-se, portanto, de Questão de competência e de hierarouia, pois tanto a lei complementar tem a competência para definir os fatos geradores, bases de cálculo e contribuintes, como a lei ordinária tem a competência para exigir o tributo, ocasião em que deve dispor e adotar tais definições, momento em Que desencadeia o fenômeno da hierarquia das leis. ${ }^{29}$

Destarte, para os que defendem a existência de hierarquia entre as normas, não poderia uma simples lei ordinária derrogar uma norma complementar, mesmo que esta não tratasse de matéria Que necessitasse da edição de lei complementar, uma vez Que esta foi elaborada mediante Quorum privilegiado e maioria absoluta.

A tese da hierarquia entre a lei complementar e a lei ordinária passou rigidamente a ser Questionada por josé Souto Maior Borges, Quando sustentou que:

o art. 46, da Constituição de 1967 não expressava eualiuer benefício de ordem no tocante à hierarquia. Segundo o doutrinador concluir que a lei complementar seria hierareuicamente superior apenas por estar situada, no elenco do art. 46, imediatamente abaixo das emendas constitucionais e logo acima das leis ordinárias, seria tão descabido Quanto sustentar que as leis delegadas e os decretos-leis, por estarem abaixo das leis ordinárias, seriam hierareuicamente inferiores a esta. A hierarquia, para o direito, ocorre sempre Que uma norma (inferior) retirar o fundamento de validade formal ou material de outra (superior). ${ }^{30}$

Conforme Souto Maior Borges, o problema da possibilidade de ser a lei complementar revogada por lei ordinária seria um falso problema. A interpretação sistemática de repartição de competência indicaria Que:

se a lei complementar (a) invadir o âmbito material de validade da legislação ordinária da União, valerá cuanto uma lei ordinária federal, se, inversamente, (b) a lei ordinária da União invadir o campo da lei complementar estará eivada

2V VITTORIO, Cassone. Direito Tributário: fundamentos constitucionais da tributação, classificação dos tributos, interpretação da legislação tribulária, doutrina, prática e jurisprudência. 16. cd. São Paulo: Altas, 2004, p. 55.

${ }^{30}$ BORGES, José Souto Maior. Op. cit., p. 23-24. 
de visceral inconstitucionalidade porQue a matéria, no tocante ao processo legislativo, somente poderia ser apreciada com observância de um Quorum especial e Qualificado, inexiste na aprovação da lei ordinária, se ocorrem as hipóteses (c) de invasão, pela lei complementar, da esfera de competência legislativa dos Estados-membros e Municípios ou (d) de a lei ordinária dos Estados-membros e Municípios invadir o campo privativo da lei complementar, estaremos diante de atos inconstitucionais do Congresso ou das Assembléias Legislativas e Câmaras de Vereadores, conforme a hipótese. ${ }^{31}$

Do mesmo modo, Michel Temer nega tal hierareuia, pois que ambas as espécies normativas encontrariam seu fundamento de validade na Constituição, havendo então, simples delimitação de matérias para a lei complementar, Que possui, como diferença específica, apenas o Quorum de aprovação, maioria absoluta, nos termos do artigo 69 do texto Constitucional. ${ }^{32}$

Nessa mesma linha de argumentação, Ivani Silva da Luz, refere:

associo-me à corrente doutrinária Que entende Que não há hierar Quia entre a lei complementar e a lei ordinária, porque ambas encontram se fundamento de validade da Constituição: o Que há são campos materiais distintos atribuídos pela Constituição para cada espécie normativa. Assim, Quando desrespeitado o âmbito de incidência material, há uma invasão de competência legislativa.

Não existe hierarquia entres as espécies normativas elencadas no art. 59 da Constituição Federal. Com exceção das Emendas, todas as demais espécies se situam no mesmo plano. A lei complementar não é superior à lej ordinária, nem esta é superior à leì delegada, e assim por diante. $O$ Que distingue uma espécie normativa de outra são certos aspectos na elaboração e o campo de atuação de cada uma delas. Lei complementar não deve cuidar de matéria de lei ordinária, da mesma forma Que a lei ordinária não pode tratar de matéria de lei complementar ou de matéria reservada a Qualouer outra espécie normativa. De forma Que, se cada uma das espécies tem o seu campo próprio de atuação se uma espécie invadir o campo de atuação de outra, estará ofendendo a Constituição. Será inconstitucional. o eual:

Dessa mesma forma, importante destacar a lição de Celso Ribeiro Bastos, segundo

No Que diz respeito a relação existente entre lei complementar e lei ordinária, vale ressaltar, Que a lei ordinária retira a sua validade da sua conformidade com a Constituição e não da lei complementar como gostariam aqueles Que defendem a superioridade hierárQuica desta última em relaçăo a lei ordinária.

${ }^{31}$ BORGES, losé Souto Maior. Op. cit., p. 25-27.

32 TEMER, Michel. Elementos de Direito Constitucional. Săo Paulo: Revista dos Tribunais, 1999, p.: 162. 
Todavia, a lei ordinária é obrigada a respeitar o campo privativo da lei complementar estabelecido pela própria Lei Maior, da mesma maneira Que é vedada a lei complementar invadir o campo de atuação da lei ordinária. ${ }^{33}$

Por fim, no tocante ao entendimento jurisprudencial, deve-se destacar Que a contradição encontra-se presente, também, nas Cortes Superiores, na medida em Que enquanto o Superior Tribunal de lustiça defenda a hierarquia, o Supremo Tribunal Federal, guardião da Constituição Federal, defende Que não há hierarquia entre a lei complementar e a lei ordinária.

O Superior Tribunal de lustiça, em Que pese os argumentos da tese da inexistência de hierarQuia, não reconhece a alteração de lei simplesmente denominada de lei complementar, por lei ordinária. A respeito, cabe observar o seguinte extrato jurisprudencial:

TRIBUTÁRIO. EMBARGOS DE DIVERGÊNCIA. COFINS. ISENÇÃO. SOCIEDADES CIVIS PRESTADORAS DE SERVIÇOS. LC No 70/9I. LEI No 9.430/96. DL No 2.397/87. PRECEDENTES. APLICAÇĀO DA SÚMULAN ${ }^{\circ}$ 276/STT.

1. A Lei Complementar no 70/91, de 30/12/1991, em seu art. $6^{\circ}$, II, isentou, expressamente, da contribuição da COFINS, as sociedades civis de Que trata o art. $\mathrm{I}^{\circ}$, do Decreto-Lei $\mathrm{n}^{\circ} 2.397$, de 22/12/1 987, sem exigir QualQuer outra condição senão as decorrentes da natureza jurídica das mencionadas entidades.

2. Em conseQüência da mensagem concessiva de isenção contida no art. $6^{\circ}$, II, da LC $\mathrm{n}^{0} 70 / 91$, fixa-se o entendimento de Que a interpretação do referido comando posto em Lei Complementar, conseqüentemente, com potencialidade hierárquica em patamar superior à legislação ordinária, revela Que serâo abrangidas pela isenção da COFINS as sociedades civis que, cumulativamente, apresentem os seguintes requisitos:

- sejam sociedades constituídas exclusivamente por pessoas físicas domiciliadas no Brasil;

- tenham por objetivo a prestação de serviços profissionais relativos ao exercício de profissão legalmente regulamentada; $\mathrm{e}$

- estejam registradas no Registro Civil das Pessoas Jurídicas. ${ }^{34}$

PROCESSUAL CML E TRIBUTÁRIO - COFINS - ISENÇÃO - SOCIEDADES CIMS PRESTADORAS DE SERVIÇOS PROFISSIONAIS - LEICOMPLEMENTAR № 70/91 - LEIN N 9.430, DE 27.12.96 (LEI ORDINÁRIA) - DECRETO-LEI No 2.397, DE 27 DE DEZEMBRO DE 1987 - PRECEDENTES.

\footnotetext{
${ }^{33}$ BASTOS, Celso Ribeiro. A Inexistência de Hierarquia entre a Lei Complementar e as Leis Ordinárias. Revista dos Tribunais, São Paulo, ano 7, n. 26, jan.-mar./1999, p. 11-20.

${ }^{34}$ STI. S1, EREsp n. 497284, rel. Min. José Delgado, D| 09.08.2004.
} 
- Em obediência ao princípio da hierarquia das leis é ilícita a revogação, por lei ordinária, das disposições contidas na Lei Complementar n ${ }^{\circ}$ 70/91.

- A isenção da COFINS concedida pelo art. $6^{\circ}$, Il da Lei Complementar no $70 /$ 9I abrange as sociedades civis de prestação de serviços profissionais relativos ao exercício de profissão legalmente regulamentada, de Que trata o art. $1^{\circ}$ do Decreto-lei n $n^{\circ} 2.397$, de 22,12.87), exigidas somente as condiçôes decorrentes da natureza jurídica de tais entidades.

- Recurso especial conhecido e provido. ${ }^{35}$

TRIBUTÁRIO - COFINS - ISENÇÃO - SOCIEDADE LIVRE: LC N. 70/91 REVOGAÇÃO DA ISENÇÃO PELA LEI N. 9.430, DE 27/12/98.

1. Estabelecida isenção da COFINS em lei complementar, não é lícita a supressão do favor fiscal por lei ordinária.

2. Recurso especial provido. ${ }^{36}$

Todavia, como já se disse anteriormente, o Supremo Tribunal Federal, mais acertadamente, vem reconhecendo a inexistência de hierarquia entre a lei complementar e a lei ordinária.

A título de exemplo, pode-se citar o RE 336134 , onde se discutia a constitucionalidade do aumento da alíquota da Cofins através da lei ordinária 9.7 I 8/98, a suprema Corte declarou válida a majoração de $2 \%$ para $3 \%$, mesmo sob o argumento de Que a referida contribuição social havia sido criada por lei complementar (LC 70/9l).

No mesmo sentido o Supremo Tribunal Federal, no julgamento do RE 84994 também reafirmou a inexistência de hierarquia entre lei complementar e lei ordinária, porque ambas encontram seu fundamento de validade na Constituição. $O$ que vislumbra-se, na verdade, são campos materiais distintos atribuídos pela Carta Magna para cada espécie normativa. Assim, Quando invadido o âmbito de incidência material, há uma invasão de competência legisiativa. Veja-se o inteiro teor do voto do Ministro Moreira Alves no Recurso Extraordinário referido:

Como os eminentes Ministros relator e Cunha Peixoto, considero que o acréscimo de que trata o artigo lo da Lei Estadual n. 10.421/7| se choca com o disposto nos artigos 113 e 20 l do Código Tributário Nacional, uma vez Que não se enQuadra Quer na categoria de obrigação tributária principal, Quer na da obrigação tributária acessória, e a d́vida ativa tributária é a proveniente apenas do crédito tributário, Que é a contra-partida da obrigação tributária na relação jurídica desta natureza. Parece-me, entretanto, Que o conflito da norma ordinária estadual com dispositivos do Código Tributário Nacional (lei complementar) acarreta, não há ilegitimidade ou a ilegalidade daquela, mas, sim, a sua inconstitucionalidade, por invasão indébita em área

${ }^{35}$ STJ. 2 ${ }^{\text {s }}$ Turma, REsp. rel. Ministro Francisco Peçanha Martins, D| 18.02.2002.

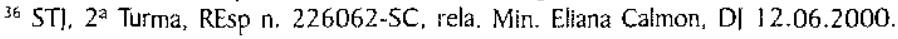


reservada, pela Constituição Federal, à lei complementar. Em casos como o presente, a doutrina se tem manifestado pela inconstitucionalidade (assim. JOSÉ AFONSO DA SILVA. Aplicabilidade das normas constitucionais, pág. 238, Ver. Dos Tribunais, São Paulo, 1968; SOUTO MAIOR BORGES, Lei Complementar tributária, pág. 27, Ver. Dos tribunais, São Paulo, 1975: NELSON DE SOUZASAMPAIO, O processo legislativo, pág. 34, Ed. Saraiva, São Paulo, 1969). Em face do exposto, acompanho o eminete relator, declarando, porém, inconstitucional o artigo la da Lei 10.421, de 3 de dezembro de 1971, do Estado de São Paulo.

O argumento de que a lei complementar goza de superioridade hierárquica, em função da posição que ocupa no artigo 59 da Constituição, acima da lei ordinária, portanto, é enfraquecido, na medida que, notoriamente sabe-se que a lei delegada e as demais espécies normativas que se encontram abaixo da lei ordinária não são inferiores a ela.

É certo, todavia, com já foi colocado oportunamente, Que a matéria reservada à lei complementar não pode ser disciplinada por lei ordinária, sob pena de inconstitucionalidade, embora o inverso seja admitido, considerando-se como válida lei complementar que trate de matéria reservada a lei ordinária, visto Que, nessa situaçăo, tem apenas aparência de lei complementar, pois, na realidade, é lei ordinária, podendo, nesse sentido, ser alterada ou revogada por legislação ordinária.

Veja-se a propriedade do voto do Ministro Moreira Alves, proferido no RE 103.639. pelo qual denota-se a perda do status da lei complementar, Quando esta versa sobre matéria reservada a lei ordinária:

É doutrina pacífica, em face do direito constitucional federal, Que só se exige lei complementar, para aquelas matérias paras quais a Carta Magna Federal, expressamente, exige essa espécie de lei, o que implica dizer Que os dispositivos Que integram formalmente uma lei complementar, mas disciplinam matéria que não está sujeita a legislação desse tipo, conservam a natureza de dispositivo de lei ordinária, podendo, inclusive, ser alterados por legislação ordinária posterior.

\section{CONCLUSÃo}

A lei complementar, em matéria tributária não assume nenhuma hierarquia constitucional com relação à lei ordinária.

Diz-se isso, pois a hierarquia é um dos recursos de que se vale o sistema jurídico para resolver os conflitos lógicos que suas proposições normativas encerrem.

Na medida em Que nosso ordenamento jurídico não é composto por um sistema de normas da mesma hierarquia, mas sim por uma ordem escalonada de diferentes normas 
jurídicas, doutrinadores sustentaram a tese da hierarQuia entre a lei complementar e a lei ordinária, com base no disposto, hoje, no art. 59, da Constituição Federal.

Todavia, como se teve a oportunidade de destacar, o art. 59, da Constituição Federal de 1988 não estabelece nenhuma ordem de hierareuia. A circunstância da lei complementar ser referida em posição anterior a lei ordináría no dispositivo citado, nada determina em termos de posicionamento hierárquico. Se este raciocínio fosse de plano aceito, então, pela mesma razão, também à lei ordinária seria hierarquicamente superior à lei delegada e à medida provisória, o Que notoriamente é falso.

A exigência de um Quorum Qualificado, por certo, indica uma maior ponderação a ser utilizada pelo legislador, ao tratar dos temas reservados à lei complementar, mas não implica Que esta seja hierarquicamente superior à lei ordinária.

A Questão da hierarquia entre normas está relacionada à norma Que the dá validade, e, no Que diz respeito à relaçâo existente entre lei complementar e lei ordinária, vale ressaltar Que a lei ordinária retira a sua validade da sua conformidade com a Constituição e пão da lei complementar como alegam aqueles que defendem a superioridade hierárquica desta última em relação à lei ordinária. A lei ordinária é obrigada a respeitar o campo privativo da lei complementar estabelecido pela própria Carta Maior, da mesma maneira Que não deve a lei complementar invadir o campo de atuação da lei ordinária.

Portanto, a Questão não é de hierarquia mas sim de competência, na medida em Que lei complementar na forma e no conteúdo só é contrastável com a Constituição e, por isso, pode adentrar em área material Que the esteja expressamente reservada. Se, porventura, a lei complementar regular matéria diversa, desbordando daquela Que the é reservada, incorre em Queda de status, pois terá valência de simples lei ordinária federal, podendo ser modificada. portanto, por simples lei ordinária. Em contrapartida, a recíproca não é verdadeira, ou seja, a lei ordinária excederá se cuidar de matéria reservada expressamente à lei complementar, sendo inconstitucional, mas não por razões de hierarquia, mas sim, porque invadiu competência Que não the cabe, não sendo possível sua recondução ao texto constitucional.

Por fim, em que pese a controvérsia jurisprudencial demonstrada entre os julgados do Superior Tribunal de lustiça - ST] e do Supremo Tribunal federal - STF, cabe salientar, por oportuno, Que, em se tratando de matéria referente a competência legislativa e não de hierarquia de normas, como aqui defendido e demonstrado, a tese da posição hierárquica superior da lei complementar face a lei ordinária, consubstanciada nos julgados do ST] mais uma vez é prejudicada, pois ao decidir sobre Questōes de natureza constitucional, como de fato são aquelas Que cercam a matéria ora em análise, o ST] usurpa funções do STF, exclusivas a esta Corte Suprema como guardiã permanente da Constituição Federal. 


\section{REFERÊNCIAS BIBLIOGRÁFICAS}

ALMEIDA, Fernanda Dias Menezes de. Competências na Constituição de 1988. 2. ed. Săo Paulo: Atlas, 2000.

ATALIBA, Gcraldo. Lei Complementar na Constituição. São Paulo: Revista dos Tribunais, 1969.

BALEEIRO, Aliomar. Direito Tributário Brasileiro. Atualização: Misabel Abreu Machado Derzi. Rio de laneiro: Forense, 2004.

BASTOS, Celso Ribeiro. A Inexistência de Hierarquia entre a Lei Complementar e as Leis Ordinárias. Revista dos Tribunais, São Paulo, ano 7, n. 26, jan.-mar./1999, p. I [-20.

- Lei Complementar: teoria e comentários. 2. ed. São Paulo: Instituto Brasileíro de Direito Constitucional, 1999.

BORGES, José Souto Maior. Isenções Tributárias. 2. ed. São Paulo: Sugestões Literárias, 1980.

. Lei Complementar Tributária. São Paulo: Revista dos Tribunais, 1975.

CARRAZA, Roque Antonio. Curso de Direito Constitucional Tributário. 17 ed. São Paulo: Malheiros, 2002.

CÊLHO, Sacha Calmon Navarro. Curso de Direito Tributário Brasileiro. 2. ed. Rio de laneiro: Forense, 1999.

DECOMAIN, Pedro Roberto. Anolações ao Código Tributário Nacional. São Paulo: Saraiva, 2000 . 1997.

ESTEVES, Maria do Rosário, Normas Gerais de Direito Tributário. São Paulo: Max Limonad,

FERREIRA FILHO, Manoel Gonçalves. Comentários à Constituição Brasileira. São Paulo: Saraiva, 2001.

FREITAS, luarez. A Interpretação Sistemática do Direito. 2. ed. São Paulo: Malheiros, 1998. KELSEN, Hans. Teoria Pura do Direito. Coimbra. 6. ed. São Paulo:Martins Fontes, 1998. ICHIHARA, Yoshiaki. Direito Tributário. 6. ed. São Paulo: Atlas, 1994. 2000.

MACHADO, Hugo de Brito. Curso de Direito Tributário. 18 ed. São Paulo: Malheiros. Saraiva, 1998.

MARTINS, Ives Gandra. Sistema Tributário na Constituição de 1988. 5. ed. São Paulo:

MIRANDA, Pontes de. Comentários à Constituição de 1967. São Paulo: RT, 1967.

MORAIS, Alexandre. Direito Constitucional. São Paulo: 2001.

PAULSEN, Leandro. Direito Tributário - Constituição e Código Tributário à Luz da Doutrina e da Jurisprudência. 6. ed. Porto Alegre: Livraria do Advogado, 2001.

REALE, Miguel. Parlamento Brasileiro. São Paulo: Saraiva, 1962.

RENCK, Renato Romeu. O Imposto de Renda da Pessoa lurídica. Do Advogado, Porto Alegre, 2001 .

SABBAG, Maristela Miglioli. Competência Tributária. Revista os Tribunais, São Paulo, jun. 1996, v. 728.

TEMER, Michel. Elementos de Direito Constitucional. Săo Paulo: Revista dos Tribunais, 1999.

TORRÊS, Heleno Taveira. Funções das Leis Complementares no Sistema Tributário Nacional: hierarquia de normas. Revista de Direito Tributário, São Paulo, n. 84.

VITTORIO, Cassone. Direito Tributário: fundamentos constitucionais da tributação, classificação dos tributos, interpretação da legislação tributária, doutrina, prática e jurisprudência. 16. ed. São Paulo: Altas, 2004. 